\title{
INTERSEISMIC HANGING WALL UPLIFT ON TETON NORMAL FAULT, GRAND TETON NATiONAL PARK WYOMING, 1988-1997, MEASURed By PRECiSe LEVELING
}

\author{
ARTHUR GIBBS SYLVESTER $\downarrow$ DEPARTMENT OF GEOLOGICAL SCIENCES \\ UNIVERSITY OF CALIFORNIA $\uparrow$ SANTA BARBARA \\ ROBERT BAER SMITH $\downarrow$ DEPARTMENT OF GEOLOGICAL SCIENCES \\ UNIVERSITY OF UTAH $\downarrow$ SALT LAKE CITY \\ CHRISTOPHER S. HITCHCOCK $\downarrow$ WILLIAM LETTIS \& ASSOCIATES., INC. \\ WALNUT CREEK $\uparrow \mathrm{CA}$ \\ JOHN ODETTE DUTTON BYRD $\downarrow$ PARADIGM GEOPHYSICAL \\ HOUSTON $\downarrow$ TX
}

\begin{abstract}
$\downarrow \quad$ INTRODUCTION
The $55 \mathrm{~km}$-long Teton normal fault at the eastern base of the Teton Range, Wyoming, has one the highest rates of Holocene slip of any fault in the Basin-Range, but it is seismically dormant at the M2+ level and presently lies in the center of a 50 $\mathrm{km}$-long seismic gap (Byrd et al, 1993). Analyses of trenching, fault scarp heights, and fault profiles indicate earthquakes on the Teton fault are nonPoissonian, with from 5 to $10 \mathrm{M}>7$ earthquakes occurring from 7,900 to 14,000 years ago, but only two such events between 5,000 and 7,900 years ago, and none in the last 5,000 years (Byrd et al., 1994).
\end{abstract}

\section{$\uparrow \quad$ LEVELING}

As part of a comprehensive neotectonic study of the interseismic behavior of the fault we have done five first order leveling surveys (1988, $1989,1991,1993,1997)$ of 50 permanent bench marks in a $21 \mathrm{~km}$-long leveling line across the fault. This line was established across the Teton fault by John O. D. Byrd and Charles Meertens to monitor possible creep and future coseismic strain (Byrd et al., 1989). It has been surveyed four times by undergraduate students of the University of California, Santa Barbara, and the University of Utah. The line was extended $7.8 \mathrm{~km}$ eastward in 1994 from the top of the bluff overlooking 
Deadman Bar, across the Snake River, to the west flank of Shadow Mountain (Sylvester, 1996). The fifth and latest resurvey of both lines was done in 1997 by volunteers associated with the University Research Expeditions Program (UREP) under the supervision of Arthur G. Sylvester and Christopher S. Hitchcock.

\section{$\downarrow \quad$ METHODS}

Two field crews, each consisting of two rod-persons, a recorder/umbrella person, and an instrument person, separately surveyed different segments of the Teton leveling line. A Wild N3 tilting level and a Wild NAK2 automatic level with optical micrometer, with matching pairs of strutsupported, double-scale, Wild GPL-3 invar leveling rods, $4003 \mathrm{~A} / \mathrm{B}$ and $6477 \mathrm{~A} / \mathrm{B}$, respectively, were used throughout each survey. The extension east of the Snake River was surveyed with the Wild N3, rods $6477 \mathrm{~A} / \mathrm{B}$, and a Leica N3000 digital level with Leica bar-coded rods 9505 and 9511 . Leveling rods $4003 \mathrm{~A} / \mathrm{B}$ have been calibrated annually by laser interferometry at the US. Navy Gage and Standards Laboratory; rods 6477A/B were first calibrated in 1989, and the Leica bar-coded rods were calibrated in 1992 and 1994. Both pairs of Wild double-scale invar leveling rods were calibrated one year before, and one year after, the 1997 survey. The leveling instruments also received routine, factory-authorized maintenance and adjustment a few weeks before each survey.

The level surveying was performed by closing a series of double-run loops from 0.5 to 3.5 $\mathrm{km}$ in length that included from two to six consecutive bench marks. Shot lengths from instrument to rod were balanced and averaged 13.2 $\mathrm{m}$. Left-rod readings were not permitted to deviate from the right-rod readings by more than 0.010 $\mathrm{cm}$, else the observation was repeated. A temperature reading was taken at the instrument for nearly every shot at a height from 1 to $1.5 \mathrm{~m}$ above the ground surface. The A-rod of each pair was always placed on a permanent bench mark to minimize errors due to differences in rod length. To minimize personnel errors, each instrument person shot the backrun of his/her forerun. In fact, considerable effort was made to make the three surveys as identical as possible; thus, all three surveys were performed at the same time of year, with the same instruments and with some of the same personnel.
The leveling data were recorded and preliminary closure errors were calculated in the field. Closure errors and relative bench mark heights were recalculated at the end of each day to check for errors in the field notes. Following each survey, except the 1997 survey, the data were submitted to the National Geodetic Survey (NGS) for analysis in its computer program REDUC4 to adjust the field observations for collimation and rod errors, differences in rod length, temperature, and refraction, if any. One of the main conclusions that came from a detailed analysis of the Teton leveling data is that they are virtually uncontaminated by refraction because of the relatively short sight lengths. The observed data are degraded, however, by the REDUC4 adjustments, because REDUC4 was intended to adjust good 2nd-order data to 1storder, Second Class standards. Thus the data presented in this report are observed data, rather than adjusted data.

\section{PRECISION OF SURVEYS}

We sought to achieve a precision of surveying closure considered "tectonic precision" which is equivalent to $1 \mathrm{~mm} \times \mathrm{L}^{-1 / 2}$ (where $\mathrm{L}$ is the one-way length of the line in kilometers), as

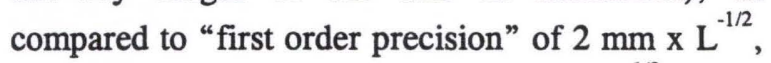
and "second order precision" of $5 \mathrm{~mm} \mathrm{x} \mathrm{L}^{-1 / 2}$. Thus a precision of one part per million is equivalent to "tectonic first order" precision, and is considered the minimum acceptable level of precision to document tectonic movement by geodetic techniques.

The standard error, $\mathrm{s}_{\mathrm{S}}$, of a single measurement was calculated using the method of proportionality:

$$
\sigma_{s}=\sqrt{\sum\left(\frac{d_{1}}{2}\right)^{2}+\left(\frac{d_{2}}{2}\right)^{2}+\ldots+\left(\frac{d_{n}}{2}\right)^{2}}
$$

where $\mathrm{d}=$ the misclosure for an individual survey segment in $\mathrm{cm}$. The probable error, or two standard deviations, for a single measurement is expressed by: 


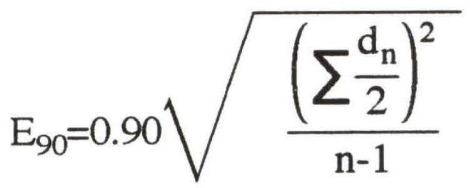

where $\mathrm{n}=$ the total number of survey loops between adjacent bench marks in a survey. Each of the five surveys yielded a standard error of from 5 to 7 parts in 10 million, well within the prescribed limits, and allowing, thereby, confident comparisons among all five surveys.

\section{RESULTS}

The leveling results (Fig. 1) indicate that from 1988 to 1997 the alluvium-filled valley of northern Jackson Hole (hanging wall) rose nearly 5 $\mathrm{mm}$ relative to bedrock of the Teton Range (footwall). Additionally, nearly $13 \mathrm{~mm}$ of the valley uplift is localized within a $2-\mathrm{km}$ zone adjacent to the fault. This zone coincides with an area of low topography characterized by lakes and ponds along the fault and streams that flow south parallel to the range, rather than eastward away from the range. These topographic features provide a record of hanging wall subsidence related to long term faulting.

The observed uplift of the valley floor and subsidence zone may reflect an apparent, reverse displacement along the fault in local crustal shortening. Recent regional GPS measurements (1987 to 1995) support that hypothesis, indicating a component of local E-W shortening in the Teton area. Alternatively the uplift may reflect a complex combination of other processes including localized poroelastic effects, differential displacement on buried, unknown faults beneath the valley, gravitational relaxation of the Teton Range, or nearfield drag of the hanging wall as it subsides overall in farfield extension. Independent evidence, such as water well data, do not exist to allow choices among these hypotheses. The next resurvey is provisionally scheduled for the year 2000 .

\section{EXTENSION TO SHADOW MOUNTAIN}

We resurveyed the extension of the original leveling line in August 1997 (Fig. 2). The data are extrapolated into a straight line that trends $\mathrm{N} 06^{\circ} \mathrm{W}$, in contrast to the main line that trends $\mathrm{N} 87^{\circ} \mathrm{W}$.
GT01 of the main line is arbitrarily held fixed and is at the north end of the extended line in this graph. Since 1994, five bench marks subsided about $3 \mathrm{~mm}$ relative to GT01, whereas five at the south end of the line rose $5 \mathrm{~mm}$. GTJ, among the five that subsided, is a bench mark in a large rock on the floor of a small canyon - it may not be stable. The five bench marks at the south end of the line are in a thin layer of alluvium on the west flank of Shadow Mountain. The queried faults coincide with topographic lineaments, including the front of Shadow Mountain. The displacements do not reflect the topographic profile, indicating that the faults are young or that any topographic expression they may have had has been modified by erosion. Clearly this line requires several resurveys in the future to establish its long term behavior.

\section{ACKNOWLEDGMENTS}

This research has been funded variously by the National Science Foundation, the National Earthquake Hazard Reduction Program, the National Park Service, the University Research Expeditions Program, and the Teton Science School. The project owes a considerable debt of appreciation to the 1997 UREP volunteers for their efforts in resurveying the original line. Those volunteers were Erin Bower, Kenneth Craig, YeeBien Chuah, Mark Hughes, Curtis Joe, Jennifer Caci, Randy Kahn, and Louis and Lucia Fermelia.

\section{$\downarrow$ LITERATURE CITED}

Byrd, J. O. D., R. B. Smith, and A. G. Sylvester, 1989. Bench mark descriptions, 1st order level line, Cascade Canyon to Deadman Bar, Grand Teton National Park, Wyoming. Department of Geology and Geophysics internal report, University of Utah, Salt Lake City, 23 p.

Byrd, J. O. D., R. B. Smith, and J. W. Geissman, 1994. The Teton fault, Wyoming: Topographic signature, neotectonics, and mechanisms of deformation. Journal of Geophysical Research 99, 20,095-20,112.

Sylvester, A. G., 1996. Snake River, Wyoming, crossing with the Leica NA3000 digital level. Survey Review 33, 383-388. 


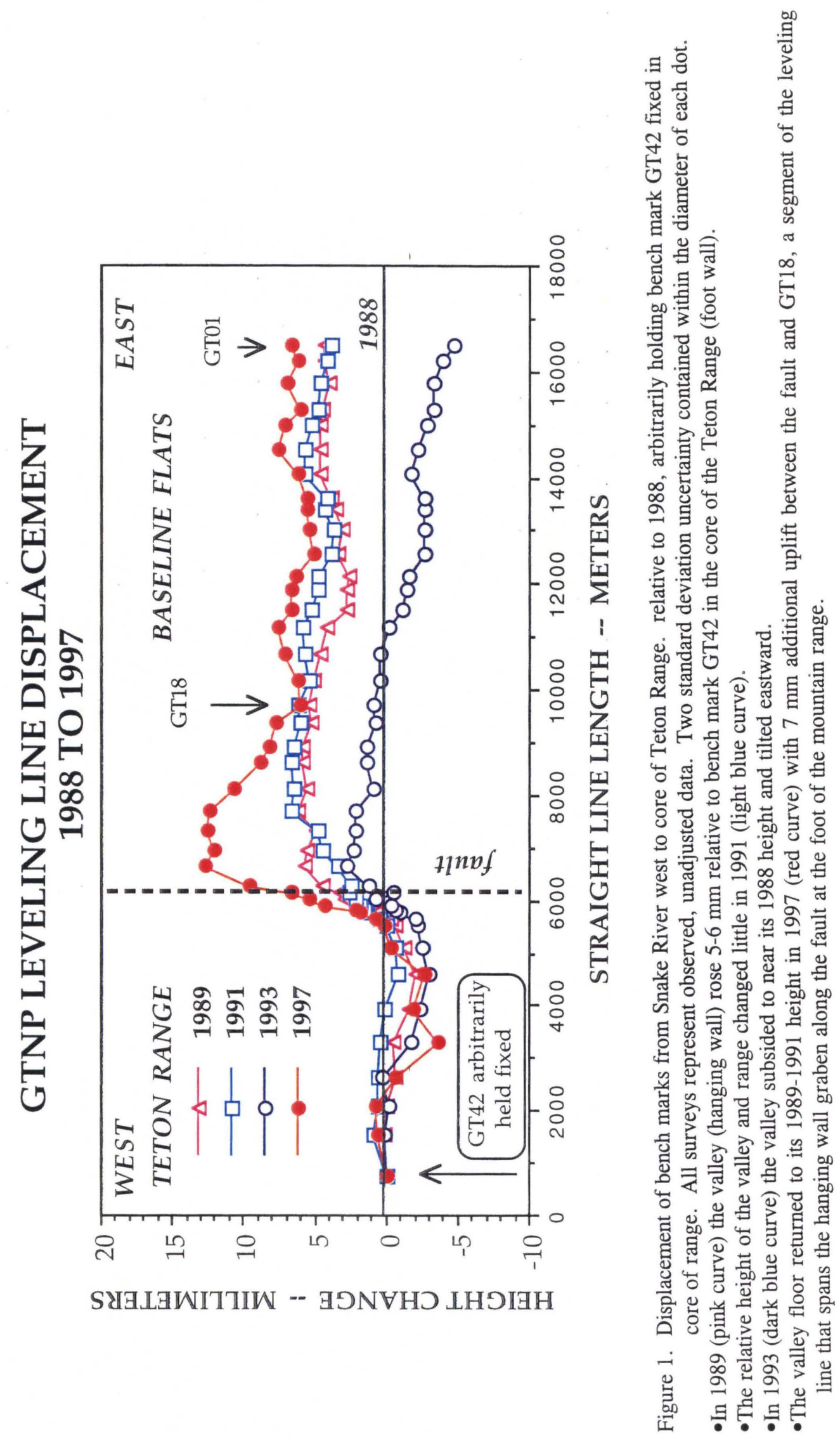



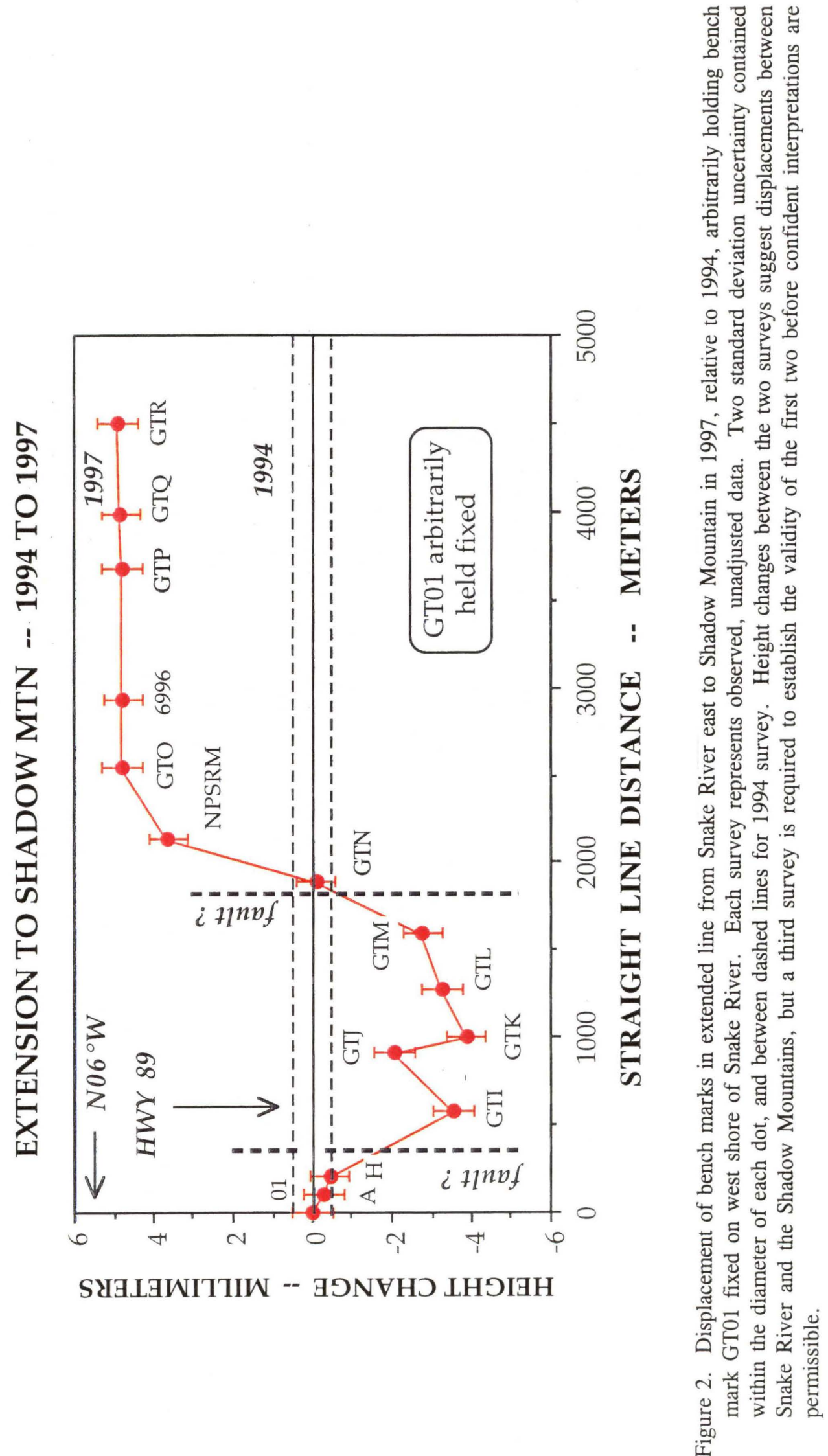